\title{
Erratum to: Gabapentin Enacarbil
}

\section{In Patients with Restless Legs Syndrome}

\author{
Lesley J. Scott
}

Published online: 19 December 2012

(C) Springer International Publishing Switzerland 2012

Erratum to: CNS Drugs (2012) 26:1073-1083

DOI 10.1007/s40263-012-0020-3

A Published-Ahead-of-Print version of this article was made available online at http://adisonline.com/cnsdrugs/ toc/publishahead on 1 December 2012. An error was subsequently identified in the article, and the following correction should be noted:

Abstract Table caption, which previously read: "Key features and properties of clobazam $\left(\mathrm{Onfi}^{\mathrm{TM}}{ }^{\text {; Frisium }}{ }^{\mathrm{TM}}\right.$, Urbanol $^{\mathrm{TM}}$ )"

should read: "Key features and properties of gabapentin enacarbil (Horizant ${ }^{\circledR}$ [USA]; Regnite ${ }^{\circledR}$ [Japan])"

The online version of the original article can be found under doi:10.1007/s40263-012-0020-3.

L. J. Scott $(\bowtie)$

Adis, 41 Centorian Drive, Private Bag 65901, Mairangi Bay,

North Shore, 0754 Auckland, New Zealand

e-mail: CNS@adis.com 